\title{
Impact of Budgetary Participation and Organizational Commitment on Managerial Performance in Nigeria
}

\author{
Adenuga Abiola Oluwalope ${ }^{1} \&$ Ojediran Sunday ${ }^{2}$ \\ ${ }^{1}$ Department of Accounting, University of Lagos, Nigeria \\ ${ }^{2}$ Department of Accountancy, Yaba College of Technology, Nigeria \\ Correspondence: Adenuga Abiola Oluwalope, Department of Accounting, University of Lagos, Nigeria
}

Received: June 3, 2017

Accepted: July 7, 2017

Online Published: July 16, 2017

doi:10.5430/afr.v6n3p48

URL: https://doi.org/10.5430/afr.v6n3p48

\begin{abstract}
Following the prevailing uncertainties in Nigerian business environment, managers and stakeholders require the need to be poised, prepared and plan to compete favourably under the rapidly shifting condition in order to remain relevant and profitable. This study examines the relationship between budget participation, organizational commitment and managerial performance in Nigeria. Primary data were obtained from copies of questionnaire distributed to members of staff at managerial levels at Nestle NIG-food, Nigerian Breweries-drinks, Flour mills-food, 7 up Bottling company-drinks, Cadbury-food, Unilever-food, Vitafoam NIG-others categorized based on the nature of their business and analysed through use of Statistical Package of Social Science (SPSS, Version 20) as correlation and regression were used to evaluate relationships among variables. Findings revealed that participation in budget activities and commitment to work done by individuals in an organization positively impacts managerial performance, hence this assertion cannot be overlooked or ignored as it supports the empirical body of positive impacts. It is therefore recommended that organizations should engage in activities that will promote budget participation and commitment and also consider other processes and events that could be explored upon towards enhancing managerial performance.
\end{abstract}

Keywords: Budget Participation, Organizational Commitment, Managerial Performance

\section{Introduction}

The budget is an integral success factor in every facet of the economy. It is that unbiased financial fit, measuring the operation that gears the fiscal wellbeing of the organization (Seer 2000), also according to Reid (2002) it presents the prospects of a company in monetary terms for a future period of time.

For a successful operation of business, budgeting constitutes an essential exercise which if not in existence could hinder the achievements of a firm or business. It is a management tool used mostly by firms in processing information and reports to top managements for forecasting and control purposes (Yuen, 2007; Drury, 2008; Weetman, 2006), hence the need to involve stanch subordinates in this process in order to influence organizational output. Organizations encourage participation in the budgetary processes because it is argued that it draws into play various benefits which include an increase in employee motivation and commitment, talents among employees, enhanced sense of responsibility, job satisfaction and a speedy performance (Weil \& Maher, 2005).

Measuring the managerial performance of organization becomes a major concern due to the existence of low or high performance of staff members and the overall profitability of the organization. This therefore arouses the need to evaluate factors that could promote or foster individual interest in discharging its sole responsibility in an organization.

The remaining part of this paper is arranged in the following order: the next section explaining the objective of the research work, followed by the review of existing literatures on budget participation, organizational commitment and managerial performance. After this a brief account of the method adopted in gathering data is provided and thereafter an empirical analysis of the data employed together with the interpretation of results. The final section summarizes the result of findings together with a brief conclusion and recommendation on the subject matter. 


\subsection{Objective}

A number of scholars have made effort on trying to link the impact of budget participation and managerial performance, some of these researchers' observed a positive relationship among variables (see e.g Shields \& Shields, 1998; Weil \& Maher, 2005; Hope \& Fraser, 2003) while others reported a downbeat dependence and a few no connection at all (Kenis, 1979). These inconsistent findings led to the inference at hand which states that there is no straightforward affiliation between budgetary participation and performance leading to the suggestion of other variables, which includes motivation, commitment to organizational activities and job satisfaction (Suliman, 2002). Therefore this study is aimed at examining the impact of how budgetary participation and organizational commitment could influence the managerial success of companies in Nigeria with only companies listed on the Nigeria Stock exchange as a point of reference.

\section{Literature Review}

The setting up of a budget is vital to the effective operation of any establishment, since it enhances the accomplishment of various tasks. According to Lin and Chang (2005), a budget is not just a tool for planning (projected revenue and expenditure of a period) but also a control device used in organizations. It enhances the co-ordination of activities within that institution, and promotes communication amongst stakeholders.

\subsection{Budget Participation}

Budgetary participation as defined by Shields and Shields (1998) is the process where a manager is fully part of, affects and controls, his or her budget. The history of examining the connection between budget participation and performance dates back to managerial accounting literature (Leach-Lopez, Stammerjohan, \& McNair, 2007) and as a matter of fact budget participation has been one of the most explored topics in management accounting in the last 40 years (Shields \& Shields, 1998; Eker \& Eker, 2008). It discloses the extent managers take part in budget setting (Subramaniam \& Mia, 2001; Parker and Kyj ,2006) providing an upright channel for information-sharing that is, an upward information dissemination strategy from subordinate to superior and a downhill communication from superior to subordinate, making both the superiors and subordinates completely part of the budget process (Weil \& Maher, 2005).

\subsection{Organizational Commitment}

This is defined as a conviction internalized among members of staff which forms part of their mental being (Mathews \& Shepherd, 2002). It centers on areas relating to personal values, career status and opportunities, work participation and vocational development. Lots of research studies have categorized organizational commitment into affective and continuance commitment (Meyer \& Allen, 1997). "Affective" referring to the poignant stance possessed by an employee towards the organization and "Continuance commitment" as a mental acumen which makes employees remain or stay in an organisation. It was therefore concluded that the extent of commitment employees exhibits determines the extent of effectiveness of the organization. (Meyer \& Allen, 1997).

\subsection{Managerial Performance}

Managerial performance according to Dave and Rastogi (2004), classified a manager's role as revolving around three main areas which are the technical, conceptual and human. The proper management of the provided core function particularly the conceptual and human; could pave a way for improved yield and growth in organizations. Therefore given that managers, in order to promote productivity would have to carry out the job with and through lots of subordinates would require sharpened behavioral prowess in order to become flourishing managers. Miles (1992) explains a flourishing manager as one who utilizes authority productively; possess the capability to set limpid goals and adopting basic strategies in ensuring that they are achieved. He or she will have to get people to see deeply, buy into his dreams (plans) and do what is necessary therefore achieving managerial performance.

Budget participation and its effect on managerial performance have been reviewed by various researchers with most literature supporting the thought that participative budgeting significantly and positively affects performance (Nouri \& Parker 1998; Kren 1992 and Parker \& Kyj, 2006).

Nouri and Parker (1998) critically evaluated the relationship between organizational commitment, as well as budget adequacy as an intervening variable in the budgetary participation - job performance relationship. A survey of 139 American managers and supervisors from large corporations was used. They found that there was a direct association between the subject matter under review. 
Charpentier (1998) argued that active contribution to the budget enhances workers' budget goal, commitment and ultimately improved performance.

Chong and Chong (2002) also established that budget affects subordinates performance through information sharing, sense of control and trust, which reflects an increased commitment (Chong \& Johnson, 2007; Subramaniam \& Mia, 2001).

Despite all the positive derivations by scholars others have revealed the existence of a no-level of significance (see e.g. House 1967, Steers 1977). Lowe \&Shaw (1968) researched the sales budgeting process in a retail chain of approximately 400 shops. They found that when management used budgets to evaluate their subordinates' performance, the, subordinates (in this case the sales managers) took advantage of their positions and manipulated accounting figures.

Jones (2001) also had a disparity of opinion stating that the involvement of employees in budget participation, did not automatically lead to commitment as attaining budget goal sometimes does not demonstrate ones interest in participation but rather a coerced budgeting process.

The review literature on this study therefore reveals a result that varies, thus leading to the need to carry out an examination of this relationship in Nigeria.

The goal theory was used in evaluating this concept as emphasized by Chong and Chong (2002) and Locke and Latham, (2002).This theory looks into the need for the organizational goal to be accepted by the workers, the need for brevity, unambiguous and flexible goals (Bennett, 2009) and the essence of feedback which according to Sorrentino (2006) measures the effort required in the pursuit of organizational goals. Chong and Chong (2002) argued that the opportunity to get involved in setting organizational goals widens the feeling of being in charge and concerned which may also increase commitment to goals among subordinates. They therefore concluded that participation in goal setting makes goals look more essential to individuals, creating a larger sense of ownership among them.

This theory also appreciates the value of a fair and reasonable goal which could in turn improve the performance of employees. This has demonstrated in the works of Libby (2009) concluded that the perception of fairness could demotivate or motivate employees on the actualization of the budget goals.

\section{Methodology}

Burns and Grove (2003) define a research design as "a blueprint for conducting a study" having maximum control over events that may interfere with the validity of findings. The survey design was employed in this study with structured questions designed and administered in order to achieve the objective of the study. This was termed explanatory as Saunders, Lewis, and Thornhill, (2003) stated that reviews which establish a fundamental affiliation among variables may be termed explanatory.

The population of study relates to listed companies on the Nigeria Stock Exchange market in consumer goods category (sector) which is twenty four (24) according to the website www.african-markets.com/en/stock-markets/ngse/listed-companies (2016). The sector was selected for this research because of the nature of business, engaging in the production and manufacturing of final goods and its focus on productivity as the inability to achieve goals could lead to the end of its operation.

The twenty four companies in the population above was further divided based on the nature of their business (Drinks -7 , Food- 12 and Others 5) and a total of seven (7) companies were selected using stratified sampling technique. In all a sample of 192 employees at supervisory level was selected using simple random sampling and a cross sectional questionnaire was used in gathering empirical data from respondents in September 2016 (Nestle NIG-food, Nigerian Breweries-drinks, Flour mills-food, 7up Bottling company-drinks, Cadbury-food, Unilever-food, Vitafoam NIG-others).The data obtained were analysed using Pearson Correlation and Linear Regression as statistical tools to test the relationship between 'Managerial Performance and the independent variables Budget participation and Organizational Commitment

\section{Statistical Results and Findings}

This segment is committed to presenting the result of data analysis carried out inorder to test the proposition made using the Statistical Package for Social Science (SPSS Version 20).

Pearson correlation analysis was carried out on variables to ascertain the extent of relationship that existed among them. The results as provided in table 1 below, depicts that Managerial performance as significant correlation to Goal Commitment and Budget Participation at $1 \%$ significant level. Question15 \& 18 was used to test Managerial 
Performance while Question14 \& 1 was used to test Goal Commitment and Budget participation respectively. I contribute to the investigation and co-ordination of business activities-Performance 1 . I often achieve my budget target-Performance 2. I am concerned about the fate of this organization-Commitment. I take part in setting our company's final budget-Participation.

Table 1. Correlation between Budget Participation, Organizational Commitment and Managerial Performance

\begin{tabular}{|c|c|c|c|c|c|}
\hline & & Performance 1 & Performance 2 & Commitment & Participation \\
\hline & Pearson Correlation & 1 & $.424 * *$ & $.296^{* *}$ & $.318^{* *}$ \\
\hline \multirow[t]{3}{*}{ Performance 1} & Sig. (2-tailed) & & .000 & .000 & .000 \\
\hline & $\mathrm{N}$ & & 192 & 192 & 192 \\
\hline & Pearson Correlation & & 1 & $.268^{* *}$ & $.318^{* *}$ \\
\hline \multirow[t]{3}{*}{ Performance 2} & Sig. (2-tailed) & & & .000 & .000 \\
\hline & $\mathrm{N}$ & & & 192 & 192 \\
\hline & Pearson Correlation & & & 1 & $.233^{* *}$ \\
\hline \multirow[t]{3}{*}{ Commitment } & Sig. (2-tailed) & & & & .001 \\
\hline & $\mathrm{N}$ & & & & 192 \\
\hline & Pearson Correlation & & & & 1 \\
\hline \multirow[t]{2}{*}{ Participation } & Sig. (2-tailed) & & & & \\
\hline & $\mathrm{N}$ & & & & \\
\hline
\end{tabular}

Table 2 shows the regression model result, with the $\mathrm{R}^{2}$ value signifying the expounding power of the independent variables. This depicts that $14.4 \%$ of the variation in Managerial Performance can be explained by the independent variables. Therefore can be inferred that the $\mathrm{R}^{2}$ value is low showing that $85.6 \%$ of the variation in the dependent variable is inexplicable, denoting a weak affiliation between the explanatory variable and Managerial performance. The standard error of the estimate is 61.64 .

Table 2. Regression Model Result

\begin{tabular}{lllll}
\hline Model & $\mathrm{R}$ & $\mathrm{R}$ Square & Adjusted R Square & Std. Error of the Estimate \\
\hline 1 & $.392^{\mathrm{a}}$ & .153 & .144 & .61643
\end{tabular}

a. Predictors: (Constant), Commitment, Budget Participation

The fitness model also explained by F-ratio in Table 3 is 17.120 , which is significant at $p<0.000$ which is less than 0.05 . This means that there is major support to deduce that at least one of the explanatory variables is linearly related to Managerial Performance and the model seems to be valid.

Table 3. Analysis of Variance

\begin{tabular}{|c|c|c|c|c|c|c|}
\hline \multicolumn{2}{|c|}{ Model } & Sum of Squares & Df & Mean Square & $\mathrm{F}$ & Sig. \\
\hline \multirow{3}{*}{1} & Regression & 13.011 & 2 & 6.505 & 17.120 & $.000^{\mathrm{b}}$ \\
\hline & Residual & 71.818 & 189 & .380 & & \\
\hline & Total & 84.828 & 191 & & & \\
\hline
\end{tabular}

Table.4 shows the result of the coefficient of regression with Managerial Performance as the dependent variable. The t-values for Organizational Commitment and Budget Participation were 3.823 and 3.419 respectively which were positive but not significant. It was therefore deduced that for each effort contributed towards goal commitment and budget participation, managerial performance increases by 0.263 and 0.235 respectively holding other variables constant. 
Table 4. Summary of Coefficients of Regression Model

\begin{tabular}{|c|c|c|c|c|c|c|}
\hline \multirow[t]{2}{*}{ Model } & & \multicolumn{2}{|c|}{ Unstandardized Coefficients } & \multirow{2}{*}{$\begin{array}{l}\text { Standardized Coefficients } \\
\text { Beta }\end{array}$} & \multirow[t]{2}{*}{$\mathrm{t}$} & \multirow[t]{2}{*}{ Sig. } \\
\hline & & $\overline{\mathrm{B}}$ & Std. Error & & & \\
\hline & (Constant) & 2.793 & .301 & & 9.265 & .000 \\
\hline \multirow[t]{2}{*}{1} & Commitment & .164 & .043 & .263 & 3.823 & .000 \\
\hline & Budget Participation & .228 & .067 & .235 & 3.419 & .001 \\
\hline
\end{tabular}

\section{Conclusion}

The paper empirically examines the extent to which budget participation and organizational commitment contributes to the managerial performance of Nigerian listed companies. In achieving its objective, obtained data through a questionnaire asking questions which were believed to have relationship with Budget Participation, Organizational Commitment and Managerial performance. A sample of one hundred and ninety-two questionnaires from quoted companies in Nigeria was used. The findings revealed that a number of respondents were interested in having budget discussion at the beginning of the year with their subordinates; they saw the need to discharge their own responsibilities to achieve the overall picture which is to improve organizational performance even according to Weil and Maher, (2005). Hence the need to implement effectively budgetary participation processes in companies due to its positive effects on managerial performance and more so, identified the significant role of the intervening variable of organizational commitment between budgetary participation and managerial performance. This therefore infers that companies ought to promote the involvement in budgeting activities at all levels and also necessitate investigation into other processes and events that could foster the improvement of managerial performance.

This paper was restricted to companies categorized under the consumer goods sector of the Nigeria stock exchange hence a further research on this topic could look into the other sectors of the stock market. Also the used of other statistical tools to examine this relationship could be explored. An interview session with the respondents could be used in other to gather more thought from respondents.

\section{References}

Allen, N. \& Meyer, J. (1997). Commitment in the Workplace: Theory, Research and Application, Sage, Newbury Park, CA Retrieved from https://us.sagepub.com/en-us/nam/commitment-in-the-workplace/book6120

Ashraf, F \& Asif Khan, M. (2012). Impact of emotional intelligence on managerial effectiveness in health care: Empirical evidence from Pakistan. African Journal of Business Management Vol. 6(11), 3941-3953. https://doi.org/ 10.5897/AJBM11.685

Bennett, D. (2009). Ready, aim fail. Why setting goals can backfire. The Boston Globe, C1. Retrieved from http://archive.boston.com/bostonglobe/ideas/articles/2009/03/15/ready_aim fail/

Burns, N \& Grove, S. (2003). The Practice of Nursing Research Conduct, Critique and Utilization (4th ed). W.B. Saunders: Philadelphia, Pennsylvania. USA. https://doi.org/10.1177/089431840501800421

Charpentier, C. (1998). Budgetary Participation in a Public Service Organisation, Working Paper Series in Business Administration 2009. Retrieved from http://swoba.hhs.se/hastba/papers/hastba0003.pdf

Chong, V. K. \& Chong, K. M. (2002). Budget goal commitment and informational effects of budget participation on performance: A structural equation modeling approach. Behavioral Research in Accounting, 14, 65-86. https://doi.org/10.2308/bria.2002.14.1.65

Chong, V. K. \& Johnson, D. M. (2007). Testing a model of the antecedents and consequences of budgetary participation on job performance. Accounting and Business Research, 37(1), 3-19. https://doi.org/10.1080/00014788.2007.9730055

Drury, C. (2008). Management and Cost Accounting. London, Thomson Learning, Business Press.

Hassan, A., Mohammad, R.P., \& Hossein, P. (2015). Budgetary participation and managerial performance: The impact of information and environmental volatility. Management Science Letters, 843-854. https://doi.org/ 10.5267/j.msl.2015.7.001

Hope, J., \& Robin, F. (2003). Who needs budgets? Harvard Business Review. Retrieved from https://hbr.org/2003/02/who-needs-budgets

House, R. J. (1967). T-group education and leadership effectiveness: a review of the empiric literature and a critical 
evaluation. Personnel Psychology, 20(1), 1-32. https://doi.org/10.1111/j.1744-6570.1967.tb02266.

Jones, R. (2001). Management accounting in government: resurrecting the classic rules of budgetary theory', Irish Accounting Review, 8(2), Autumn, 45-68.

Kenis, I. (1979). Effects of budgetary goal characteristics on managerial attitudes and performance.The Accounting Review, 4, 707-721. Retrieved from https://www.jstor.org/stable/245627

Kren, L. (1992). Budgetary participation and managerial performance: The impact of information and environmental volatility. The Accounting Review, 67, 511-526. Retrieved from https://pdfs.semanticscholar.org/185d/9e6af1b889d52cf904f3ac7babf014b68ff4.pdf

Laka - Mathebula, M.R. (2004) Modeling The relationship Between organization commitment, leadership style, human resources management practice and organization trust, PHD, thesis, faculty of economics and management sciences, Universities of Pretoria, South Africa. Retrieved from http://repository.up.ac.za/bitstream/handle/2263/26078/00thesis.pdf?sequence=1

Lau, C. M., \& Tan, S. L. C. (2006). The effects of procedural fairness and interpersonal trust on job tension in budgeting. Management Accounting Research. https://doi.org/ 10.1016/j.mar.2005.10.001

Leach-Lopez, M. A., W. W. Stammerjohan, \& F.M. McNair. (2007). Differences in the role of job relevant information in the budget participation-performance relationship among US and Mexican managers: A question of culture or communication? Journal of Management Accounting Research (forthcoming). https://doi.org/10.2308/jmar.2007.19.1.105

Libby, T \& Lindsay, R. (2009). Beyond budgeting or budgeting reconsidered? A survey of North-American budgeting practice. Management Accounting Research. Retrieved from https://www.scribd.com/document/202404248/Beyond-Budgeting-or-Budgeting-Reconsidered-aSurvey-of-Nort h-American-Budgeting-Practice.

Lin \& Chang (2005). Goal orientation and Organisational commitment as explanatory factors of employee mobility. Personnel Review, 34(2), 282 -291. https://doi.org/10.1108/00483480510591462

Locke, E. A., \& Latham, G. P. (2002).Building a practically useful theory of goal setting and task motivation: A 35-year odyssey. American Psychologist, 57(9), 705-717. https://doi.org/10.1037/0003-066x.57.9.705

Locke, E. A. \& Latham, G. P. (2006). New directions in goal-setting theory. Association for Psychological Science, 15(5), 265-268. https://doi.org/10.1111/j.1467-8721.2006.00449.x

Lowe ,E.A \& Shaw, R.W. (1968). An analysis of managerial biasing: evidence from a company budgeting process. Journal of Management Studies, 304-315. https://doi.org/ 10.1111/j.1467-6486.1968.tb00990.x

Mathews, B.P. \& Shepherd, J.L. (2002). Dimensionality of Cook and Wall's (1980) British Organizational Commitment Scale Revisited, Journal of Occupational and Organizational Psychology, 75, 369-375. https://doi.org/10.1348/096317902320369767

Miles M. (1992). The Effective Manager: Semi-Tough, McGraw Hill. McShane, S. L., Von Glinow, M. Organisational Behaviour. Boston: McGraw-Hill.

$\begin{array}{lllll}\text { Nigeria } & \text { Stock } & \text { Exchange } & \text { (2016). } & \text { Retrieved }\end{array}$ https://www.african-markets.com/en/stock-markets/ngse/listed-companies.

Nouri, H. \& R. J. Parker. (1998). The relationship between budget participation and job performance: The roles of budget adequacy and organizational commitment. Accounting, Organizations and Society, 23, 467-483. https://doi.org/10.1016/S0361-3682(97)00036-6

Nouri, H. \& L. Kyj. (2008). The Effect of Performance Feedback on Prior Budgetary Participative Research Using Survey Methodology: An Empirical Study. Critical Perspectives on Accounting, 19(8), 1431-1453. https://doi.org/10.1016/j.cpa.2007.11.003

Pala, F.S, Eker.S, \& Eker, M. (2008). The effect of demographic characteristic on organizational commitment and job satisfaction. An empirical study of the Turkish health care staff. Retrieved from http://dergipark.gov.tr/download/article-file/235546

Parker, R. J. \& Kyj, L.(2006). Vertical information sharing in the budgeting process. Accounting, Organizations and Society, 31, 27-45. https://doi.org/10.1016/j.aos.2004.07.005

Rastogi, R. \& Dave, V. (2004) "Managerial effectiveness: A function of Personality Type and organizational 
components." Singapore Management Review, 26(2), 79-87. Retrieved from https://www.highbeam.com/doc/1G1-119370568.html

Reid. (2002). A critical evaluation of the effect of participation in budget target setting of motivation. Managerial Auditing Journal, 17(3), 122-129. https://doi.org/10.1108/02686900210419903

Saunders, M., Lewis, P., \& Thornhill, A. (2003). Research methods for business students,(Ed.). England: Pearson Education Limited.

Seer A. (2000). Essentials of Managerial finance, 8th Ed. The Dryden press.

Shields, J. F. \& Shields, M. D. (1998). Antecedents of participative budgeting. Accounting, Organizations and Society, 23(1), 49-76. https://doi.org/10.1016/S0361-3682(97)00014-7

SPSS (Statistical Package for Social Science) Version 20.0.

Sorrentino, D. M. (2006). The seek mentoring program: An application of the goal-setting theory. Journal of College Student Retention, 8(2), 241-250. https://doi.org/10.2190/7D9T-D30Y-N9T0-8DWL

Steers, R. M. ( 1977). Antecedents and outcomes of organizational commitment. Administrative Science Quarterly, 22, 46-56 https://doi.org/10.2307/2391745

Subramaniam, N. \& Mia, L. (2001). The relation between decentralized structures, budgetary participation and organizational commitment: The moderating role of managers' value orientation towards innovation. Accounting, Auditing \& Accountability, 14(1), 12-29. https://doi.org/10.1108/09513570110381051

Suliman, A. M. T. (2002). Is it really a mediating construct? The mediating role of organizational commitment in work climate-performance relationship. Journal of Management Development, 21(3), 170-183. https://doi.org/10.1108/02621710210420255

Weetman, P. (2006). Financial and Management Accounting: an Introduction. Edinburgh, FT Prentice Hall.

Weil, R.L. \& Maher, M.W. (2005). Handbook of Cost Management (Ed.) New Jersey: John Wiky \& Sons, Inc.

Yuen. (2007). Antecedents of budgetary participation' enhancing employee's job performance. Managerial Auditing Journal, 22(5), 512- 526. https://doi.org/10.1108/02686900710750793 


\section{Questionnaire}

\section{SECTION A: RESPONDENT'S BIO DATA}

Please tick $(\sqrt{ })$ as appropriate where the options are defined as set below:

Please tick the one which depicts your view most closely.

SA - Strongly Agree; A- Agree; I- Indifferent; D-Disagree; SD-Strongly disagree

\begin{tabular}{|c|c|c|c|c|c|c|}
\hline $\mathbf{S} / \mathbf{N}$ & STATEMENT & SA & $\mathbf{A}$ & $\mathbf{I}$ & $\mathbf{D}$ & SD \\
\hline & SECTION A :BUDGET PARTICIPATION & & & & & \\
\hline 1. & I take part in setting our company's final budget & & & & & \\
\hline 2. & My superior explains the budget clearly to me & & & & & \\
\hline 3. & $\begin{array}{l}\text { My superior listens to my views on the budget developed to enhance its } \\
\text { implementation }\end{array}$ & & & & & \\
\hline 4. & I have regular budget related discussion with my superior. & & & & & \\
\hline 5. & Budgets set for my area of responsibility are safely attainable. & & & & & \\
\hline 6. & My contribution to the budget is very important. & & & & & \\
\hline \multirow[t]{2}{*}{7.} & $\begin{array}{l}\text { My superior initiates frequent budget discussions when the budget is } \\
\text { being prepared. }\end{array}$ & & & & & \\
\hline & SECTION B: ORGANISATIONAL COMMITMENT & & & & & \\
\hline 8. & $\begin{array}{l}\text { I am willing to put in a great deal of effort beyond the normal to help } \\
\text { this organization to be successful. }\end{array}$ & & & & & \\
\hline 9. & $\begin{array}{l}\text { I would accept almost any type of job function in order to keep } \\
\text { working for this organisation. }\end{array}$ & & & & & \\
\hline 10. & $\begin{array}{l}\text { I found that the things I regard highly and that of the organization are } \\
\text { very similar. }\end{array}$ & & & & & \\
\hline 11. & $\begin{array}{l}\text { This organization really inspires the very best in me in the way of job } \\
\text { performance. }\end{array}$ & & & & & \\
\hline 12. & $\begin{array}{l}\text { I am very glad that I choose the organization to work for over others I } \\
\text { was considering at the time I joined. }\end{array}$ & & & & & \\
\hline 13. & $\begin{array}{l}\text { I talk up this organization to my friends as a great organization to work } \\
\text { for. }\end{array}$ & & & & & \\
\hline \multirow[t]{2}{*}{14.} & I am concerned about the fate of this organization & & & & & \\
\hline & SECTION C: MANAGERIAL PERFORMANCE & & & & & \\
\hline 15. & $\begin{array}{l}\text { I contribute to the investigation and co-ordination of business } \\
\text { activities }\end{array}$ & & & & & \\
\hline 16. & I participate actively in planning decisions in my company & & & & & \\
\hline 17. & $\begin{array}{l}\text { I ensure that my subordinates are well monitored to enhance their } \\
\text { development }\end{array}$ & & & & & \\
\hline 18. & I often achieve my budget target & & & & & \\
\hline
\end{tabular}

